\title{
Challenging the Anthropomorphic Master Narrative in The Elementary Forms AND Forging a More Material- IST DURKHEIMIANISM
}

Frank Pearce

\begin{abstract}
An implicit goal of The Elementary Forms of Religious Life is to show that a viable and effective morality can be developed for modern differentiated societies. Durkheim believed that for this morality to be experienced as obligatory, humankind needed to believe that its source was a living moral being with recognisably similar, albeit, more perfect, attributes to themselves. Durkheim was confident that in reality only society and, as metaphors for society, the monotheistic representations of God, fitted this criterion. Thus he was disposed to select from a range of representations of society sui generis anthropomorphic ones, thereby marginalising much of his previous work. This article draws on critical realists and Antonio Gramsci to critique Durkheim's notion of society in this text and more broadly to interrogate his use of collective subjects such as the collective conscience. His conceptual system is shown to be incoherent and somewhat tautological. But this clears the way for a new theorization involving an articulation of certain of Durkheim's valid concepts with a rather structuralist version of Gramsci's concept of hegemony. The intention here is to provide a fresh interpretation of Durkheim and develop a more materialist Durkheimianism.
\end{abstract}

Keywords: Neo-Gramscian Durkheimianism, society sui generis, hegemony, critical realism

Résumé: Un but implicite de le livre, Les formes élémentaires de la vie demonstre que la morale viable et efficace peut être développé pour les sociétés différenciées modernes. Durkheim croyait que pour cette moralité soit vécue comme obligative l'humanité devint croire que sa source était un être vivant moral vivant manifestant des attributes visiblement semblable, bien que plus parfait que eux-mêmes. Durkheim était persuad qu'en que c'est seulement dans la réalité de la société et, comme des métaphores de la société, les représentations monothéistes de Dieu, équipé de ce critère. Ces considerations le predisposaient a choisir parmi une gamme de représentations de societe ceux anthropomorphes société 
sui generis, marginalisant ainsi beaucoup de son travail précédent. Cet article s'appuie sur "réalismes critiques" et Antonio Gramsci pour faire une critique de la conception Durkheimienne de la société dans ce texte et plus largement à interroger son utilisation de sujets collectifs tels que la conscience collective. Son système conceptual parait donc incohérente et quelque peu tautologique. Mais cette ouvre la possibilite dans ses textes à une nouvelle théorisation impliquant une articulation des certains concepts valides de Durkheim avec une version plutôt structuraliste de l'hégémonie qui ouverte la voie à une plus matérialiste Durkheimianisme.

Mots clés: Néo-Gramscien Durkheimianism, société sui generis, hégémonie, réalismes critiques

\section{INTRODUCTION}

This article provides a new reading of Durkheim's corpus through a critical, yet appreciative engagement with The Elementary Forms of Religious Life (hereafter EFRL). The first part provides a critical explanation and interpretation of Émile Durkheim's EFRL, but then refers back to some of his earlier writings to show that they are replete with interesting insights which were subsequently marginalised. The second part develops a new interpretation of sui generis social beings. It draws first on some critical realist reflections upon "Strong Emergentism" and "Relational Emergentism." Later, armed with insights gleaned from Antonio Gramsci's concept of "Hegemony", a critical interrogation of the concept of the Collective Conscience (hereafter the CC) renders it free of anthropomorphism. The result is a more nuanced sense of the components of social order that enables us to more adequately grasp the complexity of modern societies.

The EFRL is an innovative, provocative, iconoclastic, and wideranging text. It has generated numerous interpretations, most of which indicate their appreciation for Durkheim's scholarship, imagination and boldness in taking on the subject of religion. Those who attend to his argument it its entirety generally acknowledge the text's power and elegance, while also identifying key weaknesses that undermine its overall coherence (Pickering 1984). It is thus not surprising that Durkheim's text fares best when it is used selectively; this is never easy, however, if one wishes to avoid syncretism. Georges Bataille, Roger Caillois and Michel Leiris, French social theorists associated with the Collège de sociologie that met in Paris in the 1930s (Pearce 2003; 2003a) offer examples of this. 
From his earliest writings, Durkheim struggled to find ways to grasp, analyze, and represent the kind of entity or being that is "society." $\mathrm{He}$ believed that political theorists and political economists had failed to adequately grasp its nature. Their voluntaristic and individualistic epistemologies blocked their ability to understand that "(a) whole is not identical to the sum of its parts, even though, without them, it would be nothing. In the same way by coming together in a definite structure and through lasting bonds, men form a new entity, which has its own nature and its own laws. This is the social entity" (Durkheim 1978 [1888]: 51).

\section{The Elementary Forms of Religious Life: A Brief Account}

In the EFRL Durkheim argues that all societies require and benefit from religion.

[T]here is something eternal in religion that is destined to outlive the succession of particular symbols in which religious thought has clothed itself. ...[M]oral remaking can only be achieved through meetings, assemblies, and congregations in whom the individuals, pressing close to one another, reaffirm in common their common sentiments (EFRL: 429).

Intrinsically oriented to the collectivity, religious phenomena are comprised of beliefs (states of opinion consisting of representations) and rites (particular modes of action). These presuppose that real or ideal things can be classified as members of either one or the other of two mutually and absolutely exclusive genera: the sacred and the profane (EFRL: 34). The exclusion is not merely linguistic but "sacred things are things protected and isolated by prohibitions; profane things are those things to which the prohibitions apply" (EFRL: 38). While the distinction between the sacred and the profane is universal, the same is not true of its content. In each society particular collective representations indicate what is sacred and what is profane. Sacredness does not derive from qualities of the object itself, since any particular object may be categorized in one society as sacred and in another as profane. Qualities are seen as admirable because a particular society already has qualities that it has deemed valuable and then ascribes to objects it holds to be "sacred." Such sacred things create feelings of awe and elicit acts of deference. Given that generally speaking, sacred objects are scarcer than profane ones it is likely that a normal pre-condition for the sacred is scarcity of some kind. The selection of sacred flora or fauna may have aleatory dimensions and may well be associated with relatively dangerous situations. Once sacralised he, she or it may themselves gain sacralising power. These pow- 
ers may well be amplified if a sacred zone is visited. These zones tend to be associated with deities but as Durkheim argues (EFRL: 27-28), such deities are not necessary aspects of religion. Finally, these religious beliefs and practices are institutionalized in the form of "churches." This leads to Durkheim's definition of religion as a "unified system of beliefs and practices relative to sacred things, that is to say, things set apart and forbidden - beliefs and practices - which unite into one single moral community called a Church, all those who adhere to them (EFRL: 44). Acts of worship by members of a given moral community strengthen "the ties between the faithful and their god ... the god being only a figurative representation of society" and "strengthen the ties between the individual and the society" (EFRL: 227).

For Durkheim, religion is essential to social life, constituting a necessarily positive institution that creates a cosmology shared by all members. It is through this cosmology that members orient themselves towards the interests of their collectivity, and it is the cosmology that they then (re)affirm by participating in communal rituals. Religion, then, contributes to both the reproduction and development of societies.

Sacrifice is essential to the religious life. We are called upon to willingly surrender some of our autonomy, some of our time, some of our resources and capacities to the community, with no guarantee of what we may receive in return. Ritual sacrifice is of particular importance because it creates a time and place in which movement can occur between the profane and the sacred, and the sacred and the profane (EFRL: 343 ). But it is humanity's desires that motivate sacrifice; thus, in a twist of symbiosis, the divinities are revealed to be dependent on humanity for their continued existence and ability to play their part in the cosmic order (Hubert and Mauss 1964 [1898]). Human beings, then, play at least as significant a role as the gods in the imagined workings of the sacrificial mechanism, possibly effecting interconnections between a series of social and, indeed, spiritual and cosmic levels (Herrenschmidt 1982; Pearce 2010). One logical conclusion not mentioned by Durkheim is that sacrifice is integral to the life of all voluntarily joined groups and many others, including society as a whole; yet, sacrifice-per-se does not depend on religion for its existence.

\section{Continuities and Discontinuities in Durkheim's Other Writings on RELIGION}

In many ways the EFRL is a powerful culmination of Durkheim's exploration of religion and hence there is a great deal of continuity with 
his other writings on the topic. For example, from his earliest writings through to the EFRL he argued that deities do not need to play an important role or, indeed any role in any society's mythology (Durkheim 1975a [1886a]: 20-22; Durkheim 1988 [1893]: 119; Durkheim 1973c [1898] Durkheim 1995 [1912]: 27-33). Nevertheless, in his 1887 appreciative review of Jean-Marie Guyau's book L'Irréreligion de l'avenir: une étude sociologique Durkheim explored how different social relations could produce quite different imaginings of the nature of the gods. "Early societies would have been usually egalitarian and the gods in these societies were generally benevolent "beings more powerful than man but ... similar to him and live in society with him" (Durkheim 1975 [1887a]: $25)$. There would be many gods. Such societies would tend to co-exist peacefully but this could change, often for ecological reasons, or because aggressive tribes came from elsewhere and threatened those who already had settled. This threat would trigger an experience of insecurity and an increased sense of tribal solidarity. It also would tend to strengthen alliances with other nearby tribes. Inter-tribal relations and particularly alliances would often become more formalised. Each tribe would select or create a tribal god. The pantheon and the myths would become more encompassing and more structured. The gods would now be seen as powerful and distant. They would communicate with each other rather than with humanity. An individual would now be only a part of a whole whose movements he/she would follow and whose pressures he/she would accept. Religious society is not human society ideally projected beyond the stars; and a god is not conceived of as a member of a tribe. They form one or rather several societies, some friendly, others hostile, and people have maintained relationships with them of an international character (Durkheim 1975 [1887a]: 36-37). Social order would now become organised in and through the near-sovereignties of still stateless peoples and their religions and their deities would have been shaped in accord with this. The duress of war and its continual threat would have pushed societies to take on the attributes of mechanical solidarity. I am suggesting here that an approximation to sovereignty can precede the state proper, and that under those conditions treaties - somewhat like the Treaty of Westphalia although much less sophisticated - would not be uncommon.

There remains the question: what, if any, social functions are uniquely fulfilled for society by religion? This is a sociological question in that it concerns not only "all individuals taken in isolation, but society itself, that is to say the collective being [être collectif]"(Durkheim 1975a [1886a]: 18). Religion is very similar to morality and law; all three are forms of custom that deploy a "collection of commandments, 
of imperatives, sustained by material sanctions." Since the "object of law and morality" is "to maintain the equilibrium of society and to adapt it to environmental conditions" (Durkheim 1975a [1886a]: 20) we can hypothesise that religion, too, regulates society. However, it achieves this in a way that is distinct from the techniques of morality and law: religion is a collective discipline that imposes itself on both conduct and conscience and is premised upon "faith" (Durkheim 1975 [1886a]: 21). Durkheim sustained the view that faith and discipline were integral elements of religion (Durkheim 1961 [1925]).

In the absence of a clear and rigorous account of how the entity called "society" was organised, Durkheim often turned to metaphors. A more rigorous conceptualisation of the specific nature of society, with greater fidelity to its object, was still needed. As his work progressed, Durkheim increasingly drew on metaphors to better capture the dynamism of his object, society. This choice (or slippage) had negative consequences for his work. At times he seems to forget that the analogies he draws between different objects, parallel physical functions, bodies and societies are not identities but metaphors which play with systems of similarities and differences. In fact, his reliance upon metaphors leads him towards anthropomorphism; he anthropomorphises society itself, the $\mathrm{CC}$, religion, groups, groups in a state of collective effervescence and he does so particularly in the EFRL (cf. EFRL: 426, and see 22, 44, 210, 415, 420, 429). One important reason for this anthropomorphism was his understanding of the nature of morality and how it worked on a societal level. He postulated: first, that "we have no duties except in relation to thinking minds...to moral persons or thinking beings" (Durkheim 1953 [1924]: 49); second, the source of morality must also be a thinking being, "an authority whose superiority they acknowledge and which tells what is right" (Durkheim 1962 [1928]: 242); third, "but the only thinking being greater than man is society" (Durkheim 1975 [1899]: 93). The anthropomorphising of society has a signal importance for his theory of morality and this minimally reinforces the similar tendencies in his more general sociological theory (Lukes 1985: 414-416; Dubeski 2001: 3655).

\section{SuI Generis Entities, Critical Realism and Emergence}

Although it is important to problematize Durkheim's anthropomorphist tendencies (Milbrandt and Pearce 2011: 255-256), an underappreciated aspect of his work as a whole is the richness of the meanings of his phrase "society sui generis." He is very aware of the complexity of the societies of his day. This is clear from his early work "La science 
positive de morale en Allemagne", where he identifies much of what a complex society needs and specifies some observable relations linking functional institutions to each other and to society as a whole:

(F)rom the fact that these parts have definite relationships with and are assembled in a certain way, there results something new: assuredly a composite entity... Society is not, therefore reducible to a blurred mass of citizens. Since the social being has needs, which are its own, some of which are material it institutes and organises for their satisfaction an economic activity, which is not that of one individual or another or of the majority of citizens, but of the nation in its entirety (Durkheim 1993 [1887]: 64; and see Durkheim 1978 [1888a: 50).

Sui generis entities appear throughout Durkheim's work and are usually understood as being unified collective subjects, among other things, the $\mathrm{CC}$, Religion, Society, political assemblies, and God. The only collective entities discussed by Durkheim which are truly self-reflexive are the state based democratic assemblies with representation from the different interest groups within the society (Durkheim 1957 [1950]: 76-109).

A key part of Durkheim's theoretical concern is to explain the means by which sui generis entities are (re) produced. He was sympathetic to aspects of Schaeffle's use of biological metaphors, e.g. that there is a similarity between how in the histology of the human body one's focus "passes from the tissues to the organs" and how in the case of society "every organ is formed by the combination of five functional tissues" (Durkheim 1978a [1885]: 108). An example of a functioning and functional organ was the medieval corporation. One place where Durkheim has a discussion of social reproduction in which he develops the biological analogy fruitfully is in The Rules of Sociological Method. The conceptual system developed there is notable for its clarity and relative coherence. For example, in the case of the "normal and pathological," the deployment of the analogy shows that societies compared must be of the same species, at similar phases of development (Durkheim 1982 [1895]: 97). One can add that for a society to continue from generation to generation, it needs institutions that are functional for its reproduction and adaptation. The existence of the $\mathrm{CC}$ helps constitute resilient, conscionable and flexible social members, but these also require a continuous supply of reasonably strong social currents in balanced relationships with each other. But in their absence: "Unregulated emotions are adjusted neither to one another nor to the conditions they are supposed to meet; they must therefore conflict with each other most painfully" (Durkheim 1951 [1896]: 285). Under such anomic conditions, where there is no overarching order and there is a diminution of sociability, 
many become open to the influence of anti-communal discourses promoting anti-social conduct (e.g. favouring the option of suicide) that they would otherwise not entertain (cf. Pearce 2001: 135-142).

\section{Emergence and Critical Realism}

Critical Realism (CR) offers a partial solution to some of the quandaries found in Durkheim's account of emergent properties. In The Causal Power of Social Structures (2010), Dave Elder-Vass provides a useful and general definition of the process of emergence. The universe is populated with many different entities, each with particular values of common properties (mass, volume, colour) and each with its own distinctive properties. All parts are positioned in relation to each other and in relation to the whole, which may develop new properties. Later, in discussing emergentist ontology, Elder-Vass adds that "[T]o explain these entities, relations and properties, we need to identify the mechanisms by which the parts and relations produce the properties, the morphogenetic causes that bring this set of parts into this set of relations in the first place and the morphostatic causes that keep them so" (Elder-Vass 2010: 68).

Elder-Vass distinguishes between what he calls "strong emergentism" and "relational emergentism." The first is the phenomenon that certain proponents of emergentism claim to have discovered and what many of its opponents find an easy target. According to strong emergentism, "A property of a whole is emergent if it cannot be explained from the properties of lower-level parts and their substantial relations with each other" (Elder-Vass 2010: 29-30: emphasis added). The second, relational emergentism, argues that:

[E]ntities may possess emergent properties, which are produced by mechanisms that in turn depend on the properties of the entity's parts and how these parts are organised....Those parts would not be related in that way if they were not organised into an entity of the relevant kind, the collective power that they have when organised into such an entity is a power of the higher-level entity and not of the parts. (Elder-Vass 2010: 192-193 emphasis added).

Durkheim's practice was to identify and enumerate different elements of an entity, their relations to each other and to the latter as a totality. He also listed emergent properties, taking care to link their appearance with the concurrent presence of specific elements of the latter. For true emergence, the mere presence of different elements is not enough: "Since there are in society only individuals, it is they and they alone who 
are factors in social life", and, further that "[t]he whole can only change if the parts change, and to the same extent" (Durkheim 1885a: 632, 633 cited in Lukes 1985: 93). In short, Durkheim's early works can be understood as having already worked through many aspects of "compositional emergence" (Elder Vass 2010: 18-20; see Hardy 2011 who uses Elder Vass to strengthen a Foucaultian materialism). Durkheim shows that "society" is a composite being of heterogeneous elements, each with various powers and attributes; its combination is in definite and proportionate relationships. It exists in relation to a whole and the ultimate result is the emergence of a new "object" or "being" with different properties than its component parts.

In The Division of Labour in Society, Durkheim conceptualises a modern society of some complexity, works out much of what it needs as inputs, identifies some of the ways these needs have been met, specifies some observable relations linking together functional institutions to each other and to society as a whole. Durkheim is referring to societies which had a long history of increasing complexity:

In the capital are concentrated today... the active force of the central government, the arts, literature and large-scale credit operations. ... Whereas each town once had its ramparts and moat, now a few great fortresses are entrusted with the task of protecting the whole country... The different towns tend to develop certain specialisations... and certain areas concentrated, so that today we distinguish between university towns, civil service towns, factory towns... At certain spots or in certain areas are concentrated the large scale industries... all working for the whole country (Schmoller cited in Durkheim 1984 [1893]: 137-138).

Emergence, in both "relational" and "strong" forms, is clearly an important implicit concept in Durkheim's writings. Emergence is an important dimension of many sui generis entities. Durkheim theorized the properties of sui generis entities in two ways. In the early Durkheim, emergent properties were constituted by the arrangement of an emerging entity's elements. In his later writings, especially in EFRL, Durkheim had a less theoretically sophisticated account of emergence; he implied that properties were not so much emergent as pre-existing in an entity's constituent parts. For example, people occupying and exercising positions of authority (such as clan leaders) were assumed to derive their potency and charisma from their social position alone. However, by engaging with the early Durkheim's more nuanced and sophisticated analysis, as well as by incorporating elements of CR, an intriguing variation on Durkheim's master discourse is opened up: the relation of emergent entities to underlying social forces. 


\section{Rethinking Society ANd Groups}

Durkheim sometimes saw society as a large group which encompassed other smaller groups and institutions, and social relations including those identified by morphological analyses. He was interested in the relation between society and itself, partially realised through its $\mathrm{CC}$ and through democratic institutions (Durkheim 1957 [1950]); society and the individual; society and groups, institutions or social relations; individuals and other individuals; groups, institution and social relations with each other. This basic model is compatible with a wide range of theoretical positions.

In EFRL, however, Durkheim is very selective about the relationships he attends to. As we have seen he was strongly committed to the view that a viable society must be unified in and through its $\mathrm{CC}$, particularly in its manifestation as religion. This is at the heart of the society and is the determinate force within it. Religion, through the religious $\mathrm{CC}$, determines the content of society's collective representations involving cosmology, morals and ethics; it determines how the intermediary institutions function and how they translate these representations. This creates a neat functional system. A member of society gets basically the same message from a number of different sources.

As suggested earlier, Durkheim's use of metaphorical language, including its anthropomorphic variant, can be understood as an attempt to capture aspects of phenomena which are not captured by more available scientific discourses. The challenge is to develop concepts adequate to these phenomena, a case in point is provided by the statement below.

When society is going through events that sadden, distress or anger it, it pushes its members to give witness to their sadness, distress or anger through expressive actions. It demands crying, lamenting, and wounding oneself and others as a matter of duty. It does so because those collective demonstrations, as well as the moral communion they simultaneously bear witness to and reinforce, restore to the group the energy that the events threatened to take away, and thus enables it to recover its equilibrium (EFRL: 415-416).

While retaining its general sense I am going to slightly modify this statement by paraphrasing it to now read: The distress that the members of a society sometimes suffer may be a particularly intense manifestation of a general malaise that is for some reason affecting their society. Some of the members may react particularly strongly in a somewhat ritualised manner thereby having a shared experience including catharsis leading 
them to constitute themselves as a subgroup, strengthening their bonds with each other and with the society as a whole.

It is important to bear in mind that "when one undertakes to explain a social phenomenon the efficient cause which produces it and the function it fulfils must be investigated separately" (Durkheim 1982 [1895]: 123). This warns us to note that while the suffering that would be felt by such a new group would strengthen the group's bonds, this would not have been the only way that groups in that society could react. Some might have responded with anger, targeting those they suspect are lukewarm in their devotion. This would both create some solidarity and some serious exclusion.

There is a great deal of research on small groups relevant to the above. One type of group which has been researched quite thoroughly is ordered according to a kind of passive autocracy and a passive democracy: it consists of a consultant (who must be present all the time that the group is in session) and about 10 to 15 volunteers (who usually have somewhat more flexibility about attendance). Such a group, which is studying itself (among other things), will typically last for the time allotted it (usually enough for ten or more meetings) and with relatively high attendance by members. These groups display emergent properties which include anomie, followed by an increasingly unenthusiastic participation by group members, i.e. a passive "flight" from the group, followed, in turn, by generalised aggression, particularly against the "inadequate" group consultant; and then, finally, two people emerge who are expected to be the source of a rebirth of the group. Often this expectation is rewarded with a new ethos in the group and some innovative work (Bion 2013). Evidently a particular group's response to the events external to its focus, and the demands placed on it, would be mediated by the stage in the group's development. The important point here is that the specific emergent powers give group members possibilities to either act in accord with expectations or to act differently. Social control mechanisms often function to limit the options of the emergent entity; or, alternatively, the emergent entity may subvert the original form of social ordering in the group. Similar work has been undertaken to study larger groups of approximately forty to eighty people, monitored by two rather pro-active consultants; the main task facing a member of the group is to become integrated while preserving significant autonomy, avoiding the dangers of either being subsumed from or estranged by the group (Turquet 1975). These processes and their attendant dilemnas also occur on a societal level.

In fact, sadness, distress, anger etc. are at least partially produced by underlying structural relations affecting us in many different settings. 
We might note the extraordinarily collective nature of the grief, mourning and anger of so many British people at the death of Princess Diana and in particular how the "People"s Princess" became the icon of "true royalty" putting to shame the Queen"s formalism and Prince Charles's abuse of his masculine privileges. But Diana was never to return, she no longer had an active role in the royal melodrama. An obsequious Prime Minister helped a "contrite" Queen refurbish herself and the nation regained a "Dignified Leader." Will Princess Kate take up the challenge? The republican flame which had been growing in strength before Diana's death was blown out again but no one knows for how long. Nevertheless, it would seem unlikely that a relation between British subjects and their Kings or Queens will ever again be represented so positively as in "The Meaning of the Coronation” (Shils and Young 1955).

\section{A Neo-Durkheimian Reinterpretation of Groups}

Using a neo-Durkheimian framework it is possible to develop an analysis of groups that shows them to be sui generis entities with (some) powers that are constituted by the internal relations of their constituent parts; furthermore, in many instances they may be (at least partially) the result of underlying social pressures or tensions. Moving on, the next task is to reconceptualise the CC collective and the new social totality and establish their level of compatibility and potential for integration.

Durkheim generally works with a consensual model of society but there is also a somewhat different understanding of groups and members to be found in the DOL: "we form a part of several groups and there exist for us several collective consciousnesses," and moreover, we all have private experiences meaning that we also have an individual or personal consciousness (Durkheim 1988 [1893]: 61, 67). Bearing this in mind, the $\mathrm{CC}$ should not be regarded as merely a cumulative compendium of obligations and prohibitions, of examples of compliance and infractions, nor of short term accommodations and long term contradictions; nor as a mere chronicle of a single collectivity's dreams and nightmares, victories and defeats, successes and failures. Rather, it should be recognised as a resource for a number of different ever-changing sub-collectivities with whom there will be some agreement as to significant events, but marked differences as to how these are thought about. It provides both factual and idealised accounts of the society's past and present and potential futures which can be made into a number of different narratives.

It is true that Durkheim was more willing to focus on the disorder that precedes group conflict rather than on the content of conflict itself, 
but he saw them as in some sense connected: "Socialism ... is a cry of grief, sometimes of anger, uttered by men who feel most keenly our collective malaise" (Durkheim 1962 [1893/1928]: 41-42). The CC can reveal aspects of the social world which for some justify ever more conformity to the extant social order but which for others call for more radical changes. Thus, the $\mathrm{CC}$ is not automatically a source of consensus but it is also a site of potential interpretive dissonance not merely indicating that there are rival interpretations, but helping to produce struggles between groups as to which narrative will become the leading one.

Remembering that the $\mathrm{CC}$ is often connected with other social facts, it is no surprise that it may be construed as coercive. When Durkheim wrote that he "never regarded constraint as anything more than the visible, tangible expression of an underlying, inner fact that is wholly ideal: moral authority" (EFRL: 210), he was not necessarily denying a role for coercion in subtending a sociocultural order but merely claiming that for it to be legitimate it must be based on moral grounds (see also Datta 2010: 176-177).

Society then can usefully be thought of as a collection of groups, institutions and social relations rather than an expressive totality. This reconceptualization facilitates the possibility of identifying and developing radical aspects of Durkheim's thought, for example that the concept of the forced division of labour provides a resource to rethink the categories he deploys in Suicide: A Sociological Study and to suggest that "fatalistic suicide", contra Durkheim, is very common in our societies (Pearce 2001).

\section{Durkheim and Gramsci}

In a review of Antonio Labriola's "Historical Materialism", Durkheim criticised Labriola in particular, and Marxism, in general, for its economic and technological determinism and its tendency to treat other phenomena as ultimately being shaped to facilitate the functioning of its modes of economic production.

Not only is the Marxist premise unproven but it is also contrary to facts, which appear established. Sociologists and historians have increasingly come together in their common affirmation that religion is the most primitive of all phenomena. It is from religion that has emerged, through successive transformations, all the other manifestations of collective activity - law, morality, art, science, political forms etc. In principle everything is religious (Durkheim 1982a [1897]: 173). 
Somewhat ironically, the alternative Durkheim suggests exchanges a religious essentialism for economic essentialism. Although important to note, the issues raised in this are not my current focus.

Antonio Gramsci also challenged much Marxist theory and on some similar grounds. He was critical of theorists if they were economic reductionists, and if they used teleological explanations of development in accounting for social change. He certainly recognized the significance of class domination but believed that it was a mistake to invoke fear of repression and the confusion generated by ideological obfuscations as the main reasons that many working class people did not identify with the socialist project. Something more subtle was in play. In response Gramsci developed his theory of hegemony, which was not a turning away from, but a contribution to, the working class struggle for socialism. Gramsci saw his society as a locus of struggle between two hegemonic projects: the existing successful capitalist one and the insurgent socialist one.

Gramsci adapted the usual structure/superstructure model by stressing that there was a "necessary reciprocity between structure and superstructure a reciprocity which is precisely the real dialectical process" (Gramsci cited in Morera 1990: 1, 40). Neither continuity nor revolutionary change was in principle inevitable or impossible. Such outcomes depend on conjunctural factors, which depend on the balance of forces. This balance depends at least in part on how different classes respond to the circumstance within which they find themselves and on the effects of these responses. The key to understanding these is the concept of hegemony.

Hegemony involves "the entire complex of practical and theoretical activities within which the ruling class not only justifies and maintains its dominance, but manages to win active consent of those over whom it rules " (Gramsci 1971: 244). It is exercised by the leading fraction of the dominant class which has developed a privileged relationship with a "complex, contradictory discordant ensemble of the social relations of production" (Gramsci 1971: 366), a relatively permanent "organic" structure which must be distinguished from more superficial and transitory relations (Gramsci 1971: 177). This leading fraction must successfully persuade other members of the dominant classes to accept its leadership. Together these constitute the dominant "Historic Block." Gramsci identified two major superstructural "levels", the one that can be called "civil society", that is, the ensemble of organisms commonly called "private", and that of "political society" or "the state." Some of the subaltern classes may be offered a small role here but the laboring classes generally are disciplined as much as actively recruited. These 
two levels correspond on the one hand to the functions of "hegemony" that the dominant group exercises throughout society, and on the other hand, to that of "direct domination" or command exercised through the state and " "juridical' government" (Gramsci 1971: 12). It is important to note that implicit in this perspective is the possibility that "hegemony" may also involve some "legitimate" coercion and that social consensus, if achieved, less an expression of shared values than it is an "armed peace," involving a system of forces, which together produce stasis; it is as stable or unstable as these forces are stable or volatile.

It is a conventional wisdom that the kinds of cultural activity most likely to be acknowledged, transmitted and elaborated are simply the best of their kind, and the criteria can be moral and/or aesthetic. Further, this cultural activity has such significance only because of its intrinsic quality, and hence any relation its artists might have with members of the economic, political and social elites is of no relevance. But if one concedes that those who own and control the production and distribution of information have some influence upon its content, then it seems inevitable that what they consider is acceptable - be it high culture, or government announcements, discourses on the state of the world, or Church epistles - will naturally be disseminated more and probably heard more than those who do not have much access to this. It does not require conspiracy or manipulation for this to become the dominant worldview. But it does require attention to the social organisation of culture.

If we wish to understand more precisely how the dialectic between the transmission of information and what comes to be needed and desired by its recipients works, more attention again needs to be paid to the potential mediators in these relations and above all to the asymmetries in the system. "All men are intellectuals" Gramsci noted, "but not all men have in society the function of intellectuals" (Gramsci in Prison Notebooks excerpted in Forgacs 1999: 304). He identified two main kinds of specialized intellectuals: "organic" and "traditional." The former tend to have a reflexive relationship with the world but focus on the interests of a subgroup of the society, often, but not necessarily their class of origin. "Traditional" intellectuals differ from "organic" intellectuals in that they are often seen to be independent experts, fulfilling in a professional manner a general societal function. These are "disinterested", tied to no particular class or party or social group. Such disinterestedness is something of an illusion. It is true that they are often independent professionals and many are recruited from the same background. But whatever their own background, they tend to work for the most powerful and wealthy individuals and rarely work for poor peasants, the working class or the lumpen-proletariat. They were and are much more depen- 
dent upon the dominant classes than they wish to acknowledge. It has been noted that the Historical Block tends to remain dominant through changes in regimes and even in changes in the mode of production. Thus the same "traditional" intellectuals could work for many regimes but few are likely to support a working class revolution.

There is a social organisation of the production of knowledge and interpretations of the world and how they are transmitted, heard or read, interpreted, filtered, retransmitted, archived, retrieved, filtered retransmitted etc., but in a highly structured unequal world. Access to the means of communication is highly asymmetrical both on the level of dissemination and on the level of access. It is important to recognise that this structuring of information will also apply to the $\mathrm{CC}$, hence it too is likely to be hegemonised. Nevertheless, we know that the media are not received passively nor is their content often enthusiastically endorsed. After all, there usually are two distinct hegemonies competing to influence perceptions. Hence since the CC is often used in conflictual and intense situations and while it may seem confused, it will also be polysemic and innovative.

\section{Gramsci and Durkheim on Christianity}

Gramsci made broad bold statements about religion: a religion is "any conception of the world that puts itself forward as an ethic"; Christianity like other established religions is a "multiplicity of distinctive and often contradictory religions"; Christianity, was always "a Church divided between two fundamental elements " $[t]$ he Church as a community of the faithful ... and a clerical organization" (Gramsci cited by Adamson 2013: 270-271). These differing organizational premises are constitutive of Christianity and under some circumstances both can be satisfied by the same Church, as seems to have been true in Christianity's early years. But a great deal would change with the $313 \mathrm{CE}$ "Edict of Milan." The edict guaranteed religious tolerance and acknowledged property and other rights. It opened up the possibilities both for building more "communities of the faithful" and for an expansion of the "clerical organization" to institutionalise its priorities. Relatively quickly, this institutionalisation of an increasingly centralised and hierarchical Church marginalised the "communities of the faithful" and also made relatively rare the collective experiences of "communitas" (Turner 2012). The Church also developed a symbiotic relationship with the ruling classes that dominated these societies. 
This led to growing estrangement and the emergence of movements, which manifested themselves either as reform movements such as St Francis in the $13^{\text {th }}$ century or as heresies in the case of the Protestant Reformation. But, members of the Catholic hierarchy also declared the French Revolution a heresy. Gramsci commented:

They recognize that a scission occurred in the fundamental mentality and conception of the world and life.... Otherwise it could be impossible to account for the mass support of a population that was still profoundly religious and Catholic for the new ideas and revolutionary policies of the Jacobins against the clergy (Gramsci 1971: 192-193.)

The impulse that the French people experienced was a collective realisation that something was deeply wrong within their cosmos. To see major disjunctures in dichotomous terms was hardly new for Christians, but to recognise that this was a problem in the realm of the mundane was a perceptual shift to a class analysis. What was immediately at stake was the loss of their Church to the Princes, of the Church itself, of Principalities, and of the nation state. They wished to take it back so they could recreate "communities of the faithful" in a transformed Church. Class analysis was born as much in the peasant villages of France as in the teeming streets of Paris.

Durkheim, of course, was sympathetic to the French Revolution, and its enunciated principles were largely in accord with his own values. He was not particularly interested in evaluating the ideologies of the participants, but rather in treating the revolution as a social fact (Durkheim 1973 [1890]), much as he treated Socialism (Milbrandt and Pearce 2011: 251-254). In the EFRL he discussed the ways in which collective forces enervated individuals to become inspiring orators and agitators and groups to respond to crises with extraordinary actions, for example, when on August 4, 1789 the National Constituent Assembly met and decided to abolish Feudalism (Durkheim EFRL: 211-213). The Revolution, moreover, saw the dissolution of a creaking and cracked social order, long a simulacrum, with its reliance on smoke and mirrors becoming more and more evident.

For Durkheim, the Revolution was the final clash between, first, a long line of societies that relied upon a division of labour stalled at an early stage of development, an over-valuation, indeed sacralisation, of leaders, a related tendency to treat subjects as property and with the rigid CC typical of mechanical solidarity; second, the line of societies, originating in the communes and guilds of the Middle Ages-differentiating, 
democratic, egalitarian and based on organic solidarity. Quoting SaintSimon but also implicitly endorsing him, Durkheim noted:

Thus the history of the old system ... shows us a spectacle of an uninterrupted decadence. But at the same time that this regressive process was developing, another was occurring in reverse direction with no less significance. Industrial and scientific forces, once formed, did not manifest themselves exclusively by destructive effects, that is, by overthrowing the old social order. They gave rise to another" (Durkheim 1962 [1928]: 153).

In this context it is useful to turn to the concept of collective effervescence, which Durkheim and his group may have discussed more generally but his own conceptualisation seems to have derived from the accounts he read about Australian aboriginal societies. Collective effervescence can emerge when members of a tribal group have been engaging in physically demanding ritual activities for long periods of time — drumming, singing, dancing and using narcotics — leading them to surrender themselves to the group and to each other, often thereby transgressing various taboos. Not all creative effervescences require narcotics and frenzy, but they all require a great deal of contact with other group members. Scenes of collective effervescence are not uncommon nor is the creativity they unleash:

The periods of creation or renewal occur when men....are led into closer relationship with each other.... Such was the great crisis of Christendom, which, in the twelfth and thirteenth centuries gave birth to Scholasticism. Such were the Reformation and the Renaissance, the revolutionary epoch and the socialist upheavals of the nineteenth century. At such moments this higher form of life is lived with ... more or less complete exclusion of egoism and the commonplace (Durkheim 1953 [1924]: 91-92).

Captured in this quote from Durkheim is a sense that there seems to be some kind of oscillation between periods when societies are rigid, unequal, hierarchical, forcibly integrated, and lacking joy and when they become marked by creative effervescence more egalitarian and communitarian, more integrated. In Gramscian terms, at different times one or other of the two constituent elements of the Christian Church becomes dominant. There is an extraordinary overlap between the two theorists and theoretical places and spaces where they mutually enhance each other But I do not think that creative effervescence in a group setting is necessarily a religious phenomenon. Certainly it is associated with sacrifice because it involves surrender to the feelings created within the group and a trust in these, hence the possibility of self-sacrifice. But almost any group which one is free to join or leave and lasts more than for 
a few meetings is likely to create similar feelings of obligation and hence expects some sacrifice of autonomy in order to keep the group in existence. Religious groups are merely one example of a wider phenomenon. Gramsci, I am sure would agree, and Durkheim was ambivalent about his understanding of religion as a church of the sacred and profane. Was he widening and in a sense dethroning religion or was he "churchifying" a wide range of human conduct? The reader might ponder that question or, perhaps better, formulate new ones

\section{Conclusion}

Throughout his work, Durkheim attributed agency to sui generis entities $(\mathrm{CC}$, religions, etc.). It seemed then not to be illogical to impute anthropomorphic traits to these entities, e.g. their ability to "notice" and "name" problems, "imagine" solutions, and "intervene" in social life to ensure a functional solution to problems. One of Durkheim's translators D.F. Pocock explains this tendency to be "carried away by metaphor" as being in part due to the fact that Durkheim "was given to rhetoric, and this especially where the gender of French nouns encourage a certain anthropomorphism" (Durkheim 1953 [1924]: xxxiii.) These factors may indeed play a role but I hope it is clear that the problem lies deeper than that. The anthropomorphism derives from the need in his general sociology to conceptualise non-human agents guiding and adjusting social processes if social reproduction and evolutionary social development is to occur. In the case of morality or ethics, it stems from the need to find a supra human to legislate moral and ethical rules in order for people to feel obligated to obey their diktats. It is more logical to try to establish empirically the properties possessed by these entities by hypothesising properties and seeing what empirical evidence reveals. When their properties are established then it may make sense to conceive of these sui generis entities as institutions as well as emergentist composite beings. Whichever term is most appropriate, they will bring together heterogeneous elements some of which may include collective subjects.

Sui generis entities in combination with other sui generis entities or institutions working systemically often have the emergent property of systemic reproduction. The ability of a system to reproduce itself is an emergent property (and one not intrinsically dependent upon consciousnesses). Generally speaking, at whichever level one looks there are emergent properties. Usually some of these properties entail some autonomy, i.e. degrees of freedom greater than the ability of their generative parents to control, and possibly greater in some areas than the 
ability of the emergent system to control. As I suggested in my discussion of groups, this means that it is by no means inevitable that emergent entities will act in accordance with the expectations of their "parents" or the emergent system. This means that when different levels of organisations develop emergent powers, they may be used in ways that diverge from some overall goals of the institutions to "do other things." They may quite regularly prioritise their own immediate goals, over and above those of the wider system (so upsetting the goals "required" by the larger "perfect system"). This goes against Durkheim's assumption that systems operate in a largely harmonious manner - i.e. that these systems are morphogenetic and morphostatic — and had he not endlessly deferred detailed analyses of specific sui generis entities he might have established contrary conclusions.

If we change focus I hope it is clear that the $\mathrm{CC}$ will have some stability in its codification of social rules, social evaluations and representations of the world. But it is important to bear in mind that what Durkheim thought of as the common consciousness, the common medium of communication and shared understandings, is more accurately thought of as a dominating consciousness insofar as it becomes the usual takenfor granted reference point constituted in and through the appropriation, promulgation and circulation of powerful collective representations (or symbols). But this still can be read as presuming that society works like a functionalist's dream, that there are no contradictions, crises and conflicts, no capacity for other classes and groups of the excluded or the disillusioned to think outside of this particular box and have a significant input into the common consciousness. Insofar as there is always some disorder and some autonomy for different aspects of the social world but, particularly when a counter-hegemonic discourse is well developed, the $\mathrm{CC}$ will not be a settled discourse, but a site where meanings clash and where there will be different pressures to favour one discourse over another. Despite the current prevalence of garrulous discourses produced by and for those skilled in "knowing the price of everything and the value of nothing" (Oscar Wilde) their very banality hopefully stimulates people to look for radical alternatives, of which there were and still are many, with more intellectual and emotional depth.

This re-reading of Durkheim's early work has provided the basis for productively synthesizing a Durkheimian general sociology, liberated from the taint of anthropomorphism, with aspects of Gramscian sociology. It is hoped that the present work helps pave the way for rendering a more plausible basis for re-examining the Durkheimian concerns with social justice, solidarity, equality, democracy and thus an adequately grounded moral individualism. 


\section{REFERENCES}

Adamson, Walter Luiz. 2013. Gramsci, Catholicism and secular religion. Politics, Religion and Ideology (14): 4: 468-484.

Bellah, Robert. N. 1973. Émile. Durkheim on Morality and Society. Chicago: University of Chicago Press.

Bion, W.R. 1961. Experience in Groups. London: Tavistock.

Datta, Ronjon Paul. 2010. From political emergencies and states of exception to exceptional states and emergent politics: a neo-Durkheimian alternative to Agamben. In S. Romi Mukherjee ed. Durkheim and Violence. Chichester: Wiley-Blackwell.

Durkheim, Émile. 1978 [1885]. Review of Albert Schaeffle. Pp. 93-114 in Mark Traugott ed. and trans. Émile Durkheim on Institutional Analysis Chicago: University of Chicago Press.

Durkheim, Émile. [1885a] Revue de Ludwig Gumplowicz Grundriss der Soziologie. Revue Philosophique xx: 627-634.

Durkheim, Émile.1978 [1886. Les Études de science sociale. Revue philosophique 22: 61-80

Durkheim, Émile. 1975 [1886a]. Review. Herbert Spencer-Ecclesiastical Institutions. Pp. 13-23 in W.S.F. Pickering ed. and trans. and Jacqueline Redding trans. Durkheim on Religion: Readings with Bibliographies, London and Boston: Routledge \& Kegan Paul.

Durkheim, Émile.1993 [1887]. La science positive de la morale en Allemagne. Revue philosophique 24: Pp 33-58. Robert T. Hall ed. and trans. Émile Durkheim. Ethics and the Sociology of Morals Buffalo, New York: Prometheus Books.

Durkheim, Émile. 1975 [1887a]. Guyau, J-M. L'Irréligion de l'avenir. Pp. 24-38 in W.S.F. Pickering ed. and trans. and Jacqueline Redding trans. Durkheim on Religion: A Selection of Readings with Bibliographies, London and Boston: Routledge \& Kegan Paul.

Durkheim, Émile. 1978b [1888]. Course in sociology: Opening lecture. Pp. 43-70 in Mark Traugott ed. and trans. Émile Durkheim on Institutional Analysis, Chicago: University of Chicago Press.

Durkheim, Émile. [1888a] Le Programme économique de M. Schaeffle. Revue d'économie politique 11: 3-7.

Durkheim, Émile. 1973 [1890]. The principles of 1789 and sociology. Pp. 34-42 in Mark Traugott trans. and Norman R. Bellah ed. Émile Durkheim on Morality and Society. Chicago: University of Chicago Press.

Durkheim, Émile. 1988 [1893]. W.H. Halls trans. The Division of Labour in Society. London: Collier Macmillan. 
Durkheim, Émile. 1982 [1895]. Steven Lukes ed. and W.H. Halls trans. The Rules of Sociological Method and Selected Texts on Sociology and its Method. London: Macmillan.

Durkheim, Émile. 1951 [1896]. Ed. and trans. by George Simpson and John A. Spaulding trans. Suicide: A Study in Sociology. London: Routledge.

Durkheim, Émile. 1982a [1897]. Marxism and sociology: The materialist conception of history. Pp. 167-74 in Steven Lukes ed. and W. D. Halls trans. The Rules of Sociological Method and Selected Texts on Sociology and its Method, London and Basingstoke: Macmillan.

Durkheim, Émile. 1975 [1899]. Concerning the definition of religious phenomena. Pp. 74-99 in W.S.F. Pickering ed. and trans. and Mrs. Jacqueline Redding trans. Durkheim on Religion: A Selection of Readings with Bibliographies, London and Boston: Routledge \& Kegan Paul.

Durkheim, Émile. 1974 [1924]. The determination of moral facts. Pp. 35-62 in D.F. Pocock trans. Sociology and Philosophy, New York: Macmillan.

Durkheim, Émile. 1994 [1912]. The Elementary Forms of the Religious Life. Translated by Karen Fields. New York: Free Press. Abbreviated as EFRL.

Durkheim, Émile. 1962 [1928]. Trans, by Charlotte Sattler. Socialism: New York: Collier Macmillan.

Durkheim, Émile. 1953 [1924]. Trans. by D. F. Pocock. Sociology and Philosophy. London: Routledge

Durkheim, Émile. 1957 [1950]. Professional Ethics And Civic Morals. London: Routledge.

EFRL abbreviation for Émile Durkheim 1995 [1912]).

Elder-Vass, David. 2010. The Causal Power of Social Structures: Emergence, Structure, and Agency. New York: Cambridge University Press.

Forgacs, David. 1999. Ed. The Gramsci Reader: Selected Writings 1916-1938. New York: Schocken.

Gramsci, Antonio. 1971. Trans. by Q. Hoare and G. Nowell-Smith Selections from the Prison Notebooks of Antonio Gramsci, London: International Publisher.

Herrenschmidt, Olivier. 1982. Sacrifice-symbolic or effective? Between belief and transgression. Pp. 24-42, in Michael Izzard and Pierre Smith editors. Belief and Transgression: Structuralist Essays in Religion, History and Myth, Chicago: University of Chicago Press.

Hardy, Nicholas. 2011. "Foucault, Genealogy, Emergence: Re-examining the Extra-discursive" in Journal for the Theory of Social Behaviour 68-91.

Hubert, Henri and Marcel Mauss. 1964 [1899] Sacrifice: Its Nature and Functions, London: Routledge.

Lakoff, George and Mark Johnson. 1980. The Metaphorical Structure of the Human Conceptual System. Cognitive Science 4: 195-208. 
Lukes, Steven. 1985. Émile Durkheim: His Life and Work: A Historical and Critical Study. Stanford: Stanford University Press.

Marx, Karl and Friedrich Engels. 1970 [1845]. The German Ideology. New York: International Publishers.

Morera, Esteve. 1990. Gramsci’s Historicism: A Realist Interpretation, London Routledge.

Milbrandt, Tara and Frank Pearce. 2011. Émile Durkheim. Pp. 236-282 in George Ritzer and Jeffrey Stepnisky eds. The Wiley-Blackwell to Major Social Theorists: Volume I, Classical Social Theory, Chichester: WileyBlackwell.

Pearce, Frank. 2001. The Radical Durkheim: Second Edition. Toronto: Canadian Scholars Press.

Pearce, Frank. 2003. Introduction: The Collège de sociologie and French social thought. Economy and Society 32(21): 1-6.

Pearce, Frank. 2003a. Off with their heads: Caillois, Klossowski and Foucault on Public Executions. Economy and Society 32 (21): 48-73.

Pearce, Frank. 2010. Obligatory Sacrifice and Imperial Projects. Pp. 45-66 in ed. William Chambliss, Raymond Michalowski and Ronald C. Kramer. State Crime in the Global Age. New York: Willan Publishing.

Pickering, W.S.F. 1984. Durkheim's Sociology of Religion: Themes and Theories. New York: Routledge.

Shils, Edward and Michael Young. 1955. The Meaning of the Coronation. Sociological Review, N.S. 3: 63-8.

Stedman Jones, Susan. 2001. Durkheim Reconsidered. Oxford: Blackwell Publishers.

Traugott, Mark. 1978. Ed. and trans. Émile Durkheim on Institutional Analysis. Chicago: University of Chicago Press.

Turner, Edith. 2012. Communitas: the Anthropology of Collective Joy. London: Palgrave Macmillan.

Turquet, P. 1975. Threats to identity in the large group. Pp. 87-144 in L. Kreeger, ed. The Large Group: Dynamics and Therapy. London: Constable.

\section{ACKNOWLedgements}

The development of this paper has benefited from the patience, encouragement and insights of numerous people. First and foremost I thank the editors, Tara Milbrandt and Ronjon Paul Datta, for their tireless help in seeing this article through to completion. I would also like to thank those who read and discussed various versions of the paper with me, especially 
Lorna Weir, Nick Hardy, Elaine Stavro and Laura Thrasher. The paper has also been enhanced through rich and wide-ranging conversations I have had about Durkheim and social theory with Rod Michalko, Tanya Titchkosky, Jim Cosgrave and Jon Frauley.

Frank Pearce is Emeritus Professor of Sociology at Queen's University, Canada. He has published extensively in the areas of sociological theory, corporate crime, law, and social justice. Author of The Radical Durkheim (1989, 2001, 2012), Frank has developed a unique critical synthesis of the theories of Karl Marx and Emile Durkheim. In addition to numerous articles and co-edited collections, he has written Crimes of the Powerful (1976), Toxic Capitalism (with Steve Tombs, 1998) and Bhopal: Flowers at the Altar of Profit and Power (2012).

E-mail: pearcef@queensu.ca 